CARDIOVASCULAR MEDICINE

\title{
Increased serum concentrations of soluble CD95/Fas and caspase 1/ICE in patients with acute angina
}

\author{
H J Ankersmit, T Weber, J Auer, G Roth, M Brunner, E Kvas, B Moser, S Spreitzer, E Lassnig, \\ E Maurer, P Hartl, E Wolner, G Boltz-Nitulescu, B Eber
}

Heart 2004;90:151-154. doi: 10.1136/hrt.2003.012062

See end of article for authors' affiliations

Correspondence to:

Dr H J Ankersmit,

Department of CT Surgery,

General Hospital Vienna,

Währinger Gürtel 18-20

A-1090 Vienna, Austria;

hiankersmit@hotmail.com

Accepted 22 July 2003
Objectives: To investigate the expression of death inducing receptors in the sera of patients with stable and unstable angina.

Design: 80 consecutive patients with stable $(n=40)$ or unstable $(n=40)$ angina pectoris were studied. Serum concentrations of soluble CD95 (sCD95), soluble CD95 ligand (sCD95L; CD178), tumour necrosis factor (TNF) $\alpha$, soluble TNF $\alpha$ receptor type 1 (sTNFR1), and interleukin $1 \beta$ converting enzyme (ICE; caspase 1) were measured by enzyme linked immunosorbent assay (ELISA).

Results: Significant increases in the concentrations of sCD95 and ICE $(p<0.001$ and $p<0.023$, respectively) were found in the serum from patients with unstable angina relative to those with stable angina. There were no significant differences in the concentrations of sCD95L, TNF $\alpha$, and sTNFR1 between the groups.

Conclusions: These data provide the first evidence that SCD95 and ICE are important serological markers that may help to discriminate between stable and unstable angina. This observation may warrant further clinical study to elucidate the clinical impact of sCD95 and ICE in acute coronary syndromes.
C oronary artery disease is associated with systemic immune responses and signs of chronic inflammation. ${ }^{12}$ Apart from the well known traditional risk factors, seroepidemiological studies have suggested a link between atherosclerosis and microbial infections. ${ }^{34}$ The atherosclerotic lesions contain large numbers of immune cells, particularly monocytes, macrophages, and T cells. Most $\mathrm{T}$ cells are $\mathrm{CD}^{+}, \mathrm{CD}^{+}$, and $\mathrm{T}$ cell receptor $\alpha \beta^{+}{ }^{2}$. They are largely $\mathrm{T}$ helper cell 1 subtype, which secrete interferon $\gamma$, interleukin 2, and tumour necrosis factor (TNF) $\alpha .{ }^{5}$ These proinflammatory cytokines, as well as interleukin 1, interleukin 6, interleukin 8 , and $\mathrm{C}$ reactive protein, cause activation of $\mathrm{T}$ cells, macrophages, and vascular endothelial cells. They also augment expression of adhesion molecules, chemoattractants, and other cell surface markers. ${ }^{56}$

The maintenance of $\mathrm{T}$ cell homeostasis and peripheral tolerance to self antigens following repeated cell stimulations is regulated mainly by apoptosis. Apoptosis, or programmed cell death, is initiated by death-inducing receptors. These are transmembrane receptors that include the TNF receptors and a variety of immune cell receptors (CD95, CD40, CD30, and CD27) and their corresponding ligands. ${ }^{78}$ It has been previously shown that interaction between CD95 (Fas; apolipoprotein 1) and CD95 ligand (CD95L; Fas ligand, CD178) induces apoptosis in human plaque derived vascular smooth muscle cells. ${ }^{9}$ Activated cytotoxic $\mathrm{CD}^{+} / \mathrm{CDI} 6 \mathrm{I}^{+} \mathrm{T}$ cells can lyse capillary endothelial cells in the presence of $\mathrm{C}$ reactive protein at concentrations frequently found in patients at risk for coronary heart disease. ${ }^{10}$ In addition, patients with unstable angina have increased concentrations of shed membrane microparticles, originating from activated $\mathrm{CD}^{+}$cells, endothelial cells, and macrophages, hence indicating increased intravascular peripheral apoptotic turnover. ${ }^{11}$

It is not well known whether patients with acute coronary syndrome have increased concentrations of soluble CD95 (sCD95) and SCD95L, soluble TNF receptor type l (sTNFR1), and interleukin $1 \beta$ converting enzyme (ICE; caspase 1 ). Therefore, we investigated comparatively the concentration of these molecules, which are involved in the apoptotic pathways, in the serum from patients with stable and unstable angina.

\section{METHODS}

\section{Study group}

Eighty consecutive patients admitted to our institution for the assessment of angina chest pain were studied and had undergone coronary angiography. Table l summarises demographic and some baseline clinical characteristics. Stable angina $(n=40)$ was defined by typical exertional chest pain angina relieved by rest, glyceryl trinitrate administration, or both with positive responses to exercise ECG stress testing and $\geqslant 50 \%$ diameter stenosis in $\geqslant 1$ coronary arteries at catheterisation. Unstable angina $(n=40)$ was defined according to Braunwald. ${ }^{12}$ All patients with unstable angina class IIIB had diagnostic ST segment changes, $\mathrm{T}$ wave inversion, or both, as well as negative cardiac enzymes. No patient included in the study had evidence of ongoing systemic or cardiac inflammatory processes as defined by clinical history. Blood samples were taken at the time of admission into hospital. The investigation conformed to the principles outlined in the Declaration of Helsinki.

\section{Angiographic analysis}

Coronary angiography was carried out according to the Judkins technique. Images of the coronary tree were obtained in routine, standardised projections with standard equipment (Siemens BICORTOP, Erlangen, Germany). To assess the extent of atherosclerotic disease the coronary artery tree was

Abbreviations: CD95L, CD95 ligand; ELISA, enzyme linked immunosorbent assay; FADD, Fas associated death domain; ICE, interleukin $1 \beta$ converting enzyme; $s C D 95$, soluble CD95; sCD95L, soluble CD95 ligand; sTNFR1, soluble tumour necrosis factor receptor type 1; TNF, tumour necrosis factor; TNFR1, tumour necrosis factor receptor type 1 
Table 1 Demographic and clinical data of patients with stable and unstable angina pectoris

\begin{tabular}{|c|c|c|}
\hline & $\begin{array}{l}\text { Stable angina } \\
(n=40)\end{array}$ & $\begin{array}{l}\text { Unstable angina } \\
(n=40)\end{array}$ \\
\hline Men/women & $29 / 11$ & $29 / 11$ \\
\hline Mean age (years) & 65 & 65.4 \\
\hline \multicolumn{3}{|l|}{ History and risk factors } \\
\hline Previous CABG & $5(12.5 \%)$ & $6(15 \%)$ \\
\hline Previous PTCA & $10(25 \%)$ & $10(25 \%)$ \\
\hline Diabetes & $8(20 \%)$ & $9(22.5 \%)$ \\
\hline Hypertension & $31(77.5 \%)$ & $26(65 \%)$ \\
\hline Current smoker & $6(15 \%)$ & $8(20 \%)$ \\
\hline Former smoker & $12(30 \%)$ & $8(20 \%)$ \\
\hline Never smoker & $22(55 \%)$ & $24(60 \%)$ \\
\hline \multicolumn{3}{|l|}{ Angiographic analysis } \\
\hline Extension/severity score & $6.1 \%$ & $6.3 \%$ \\
\hline One vessel disease & $14(35 \%)$ & $18(45 \%)$ \\
\hline Two vessel diseased & $17(42.5 \%)$ & $13(32.5 \%)$ \\
\hline Three vessel disease & $8(20 \%)$ & $9(22.5 \%)$ \\
\hline Left main disease & $1(2.5 \%)$ & 0 \\
\hline \multicolumn{3}{|c|}{ Biochemistry (mean concentrations) } \\
\hline Cholesterol (mmol/l) & 5.29 & 5.43 \\
\hline LDL cholesterol (mmol/I) & 3.22 & 3.35 \\
\hline $\mathrm{HDL}$ cholesterol (mmol/l) & 1.23 & 1.12 \\
\hline Triglycerides (mmol/l) & 1.77 & 1.91 \\
\hline Creatinine $(\mu \mathrm{mol} / \mathrm{l})$ & 97.2 & 97.2 \\
\hline \multicolumn{3}{|l|}{ Left ventricular systolic function } \\
\hline Normal & $29(72.5 \%)$ & $31(75.5 \%)$ \\
\hline Mild impairment & $8(20.3 \%)$ & $3(7.5 \%)$ \\
\hline Moderate impairment & $3(7.5 \%)$ & $6(15 \%)$ \\
\hline Severe impairment & 0 & 0 \\
\hline \multicolumn{3}{|c|}{$\begin{array}{l}\text { CABG; coronary artery bypass grafting; HDL, high density lipoprotein; } \\
\text { LDL, low density lipoprotein; PTCA, percutaneous transluminal coronary } \\
\text { angioplasty. }\end{array}$} \\
\hline
\end{tabular}

assessed according to vessel score, stenosis score, and extension score. ${ }^{13}$

\section{Laboratory analysis}

Serum samples were obtained after clinical assessment grading the patient affected with stable or unstable angina and before cardiac catheterisation. Serum was then aliquoted and kept frozen. Circulating sCD95 and sCD95L were measured by a commercial enzyme linked immunosorbent assay (ELISA) with polyclonal antibodies against human CD95 (B\&D Pharmingen, Franklin Lakes, New Jersey, USA) and CD95L (MBL Co Ltd, Nagoya, Japan). The concentration of TNF $\alpha$ and sTNFRl (p55; CD120a) was measured by ELISA with polyclonal antibodies against human TNF receptor type l (TNFRl) and TNFa (R\&D Systems Inc, McKinley, Minnesota, USA). ICE was measured in the serum by ELISA with monoclonal antibody to ICE l antibody (Bender MedSystems, Vienna, Austria). The sensitivity of the ELISA was $20 \mathrm{pg} / \mathrm{ml}$ for sCD95 and SCD95L, $3 \mathrm{pg} / \mathrm{ml}$ for sTNFRl, $80 \mathrm{pg} / \mathrm{ml}$ for TNF $\alpha$, and $5 \mathrm{pg} / \mathrm{ml}$ for human ICE. The analytical unit of the biochemistry department following standard methods carried out all other biochemistry measurements.

\section{Statistical analysis}

Results are presented as mean (SEM) for continuous, normally distributed variables and as percentages for categorical data. Continuous variables were analysed by two tailed $t$ test for unpaired observations. A probability value of $\mathrm{p}<0.05$ was considered significant. The statistical software package SPSS (SPSS Inc, Chicago, Illinois, USA) was used for all calculations.

\section{RESULTS}

\section{Demographic and clinical features}

Table 1 presents baseline characteristics of patients with stable and unstable angina. In both groups, a similar proportion of patients had a history of myocardial infarction or previous coronary interventions (coronary artery bypass graft or percutaneous transluminal coronary angioplasty). Established risk factors for coronary artery disease were similar in the two groups. Total cholesterol concentrations did not differ significantly between the groups. Angiographic findings were similar in both groups. The chronic stable angina group had slightly higher extension scores but this did not reach significance.

\section{Soluble death inducing receptors and ICE concentrations}

The results listed in the table 2 show a significant increase in the concentration of ICE in serum from patients with unstable angina $(\mathrm{p}<0.023)$. The concentrations of sCD95L, $\mathrm{TNF} \alpha$, and STNFRl were not significantly different (table 2 ). Interestingly, as shown in fig 1 , the concentration of sCD95 was greatly increased in the unstable angina group compared with the stable group (mean (SEM) 3235.78 (380.2) and 668.23 (143.1) pg/ml, respectively; $\mathrm{p}<0.001$ ).

\section{DISCUSSION}

Our study showed for the first time that serum SCD95 and ICE concentrations are significantly higher in patients with unstable angina than in patients with stable angina. This

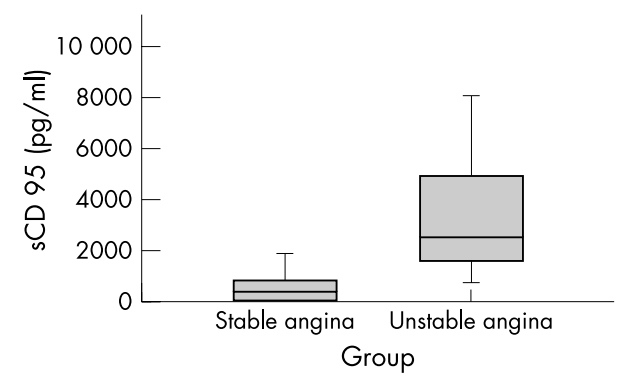

Figure 1 Concentration of soluble CD95 (sCD95) in the serum of patients with stable and unstable angina. Box plot shows the median, quartiles, and extreme concentrations of sCD95. Differences were significant $(p<0.001)$.

Table 2 Soluble death inducing receptors (sDIR) in patients with stable and unstable angina pectoris

\begin{tabular}{llll}
\hline sDIR and cytokines & Stable angina $(\mathbf{n}=40)$ & Unstable angina $(\mathbf{n}=40)$ & $p$ Value \\
\hline sCD95L $(\mathrm{pg} / \mathrm{m})$ & $78.29(1.2)$ & $62.34(10.3)$ & 0.26 \\
ICE $/ \mathrm{caspase} 1(\mathrm{pg} / \mathrm{m})$ & $46.94(6.2)$ & $78.21(13.1)$ & 0.023 \\
sTNFR1 $(\mathrm{ng} / \mathrm{m})$ & $1.72(0.2)$ & $1.42(0.3)$ & 0.39 \\
TNF- $\alpha(\mathrm{pg} / \mathrm{m})$ & $15.55(6.4)$ & $17.43(5.4)$ & 0.83 \\
\hline
\end{tabular}

Data are mean (SEM).

sCD95L, soluble CD95 ligand; ICE, interleukin $1 \beta$ converting enzyme; TNF, tumour necrosis factor; sTNFR1, soluble TNF receptor type 1. 
suggests that increased apoptosis specific markers are associated with clinical instability. We have also found that the serum concentrations of TNF $\alpha$, sTNFRl, and SCD95L were not significantly different in the study cohorts. These results indicate that patients with unstable angina may be in a paradoxical state of increased apoptotic turnover, as indicated by increased secretion of sCD95 and ICE/caspase 1.

Apoptosis is a highly organised, controlled, and energy dependent mechanism whereby a cell commits suicide. Distinct morphological features such as cell shrinkage, chromatin condensation, DNA fragmentation, membrane blebbing, and formation of apoptotic bodies are characteristic of this cell death mechanism. A family of cysteine proteases, termed caspase, the mammalian homologue to the Caenorhabditis elegans cell death gene CED $3,{ }^{14}$ play a pivotal part in apoptosis, particularly caspase 8 , which initiate the caspase activation cascade through caspase 3 and caspase $9 .^{7-15}$ Caspases are present in the cell in an inactive form and are activated by autoproteolytic processing, oligomerisation, and heterocleavage by other caspases or granzyme B. Activation of caspase requires transduction of a signal from cell membrane receptors, such as CD95 and TNFRl. Binding of ligand to death inducing receptors leads to trimerisation and cross linking of the aggregated cytoplasmic domain of the receptor complex and recruitment of the so called Fas associated death domain (FADD; MORTIl), TNFRl associated death domain (TRADD), FADD-like ICEl (FLICE1; MACHl; caspase 8), or FLICE2/caspase $10 .^{78}$

The role of ICE in apoptosis and its potential to interfere in the activity of atherosclerotic lesions and plaque stability is not well understood. It has been shown that ICE cleaves the $31 \mathrm{kDa}$ interleukin $1 \beta$ precursor protein at Aspl16-Alal17, whereby it creates the mature biologically active interleukin $1 \beta$, a key mediator of inflammation. ${ }^{16}$ Interestingly, ICE can also cleave an inactive precursor of interferon $\gamma$ inducing factor or interleukin $18^{17}$; thus, ICE regulates production of interferon $\gamma$ and subsequently $\mathrm{T}$ cell activation. Although vascular smooth muscle cells express ICE, an ICE inhibitor suppresses the release of mature interleukin $1 \beta .^{18}$ This may be a novel regulatory mechanism in vascular biology and pathology.

The cell death machinery is tightly controlled by Bcl-2, a member of a large gene family encoding proteins that can either promote (for example, Bax, Bak, Bid, and Bad) or inhibit (for example, Bcl-2 and Bcl- $\mathrm{H}_{\mathrm{L}}$ ) apoptosis. ${ }^{19}$ The nuclear factor $\kappa \mathrm{B}$ pathway is a further key component of the cellular response to a variety of stimuli. The multiplicity of mechanisms whereby the transcription factor nuclear factor $\kappa \mathrm{B}$ serves the pro-apoptotic or anti-apoptotic function is complex and may be determined by the nature of the death stimulus rather than by the tissue origin..$^{20}$ Other important regulators of apoptosis act at the level of caspase. Such proteins include cellular FADD-like inhibitory protein and the inhibitor of the apoptosis family, which counteracts the effect of the caspase inhibitors themselves. ${ }^{21}$ The roles of sCD95 and sCD95L as pro-apoptotic and anti-apoptotic molecules are not clearly defined. The CD95 antigen is expressed on $\mathrm{T}$ and $\mathrm{B}$ cells, granulocytes, monocytes, and natural killer cells, particularly on activated cells. CD95 is cleaved by proteolytic enzymes produced by inflammatory cells and SCD95 is generated by alternative mRNA splicing. It has been previously shown that supernatants containing sCD95 can inhibit anti-CD95 antibody induced apoptosis, hence indicating that sCD95 may block signal transduction and apoptosis. ${ }^{22}$ Overexpression of sCD95 protects the integrity of the vessel wall from immune injury and attenuates transplant arteriosclerosis. ${ }^{23}$ Furthermore, an increased concentration of SCD95 has been regarded as a predictor of active atherosclerosis in patients with end stage renal disease. ${ }^{24}$ CD95L is expressed on activated $\mathrm{T}$ cells, natural killer cells, and vascular endothelial cells. ${ }^{25}$ CD95L is cleaved from the cell membrane by a metalloproteinase-like enzyme. sCD95L may be detected in the serum ${ }^{26}$ and considered to be a marker of atherosclerosis. ${ }^{27}$

The coexistence of increased apoptotic turnover and secretion of the apoptosis prohibiting sCD95 molecule may be a desperate attempt by the immune system in unstable angina to overcome lifelong and constant triggering of autoreactive $\mathrm{T}$ cells by way of the $\mathrm{T}$ cell receptor. We are tempted to believe that SCD95, sCD95L, sTNFRl, and ICE are serological markers that may help to discriminate between stable and unstable angina. We conclude that our results showing increased concentrations of SCD95 and ICE in unstable angina may merely reflect inflammatory cell activation and the role in relation to apoptosis specific immune activation remains to be determined. However, to elucidate the role of these molecules in the pathogenesis, disease progression and destabilisation, diagnosis, and prognosis of acute coronary syndromes further clinical studies as well as new experimental designs are needed.

\section{ACKNOWLEDGEMENTS}

This study was supported by grant 9449 of the Austrian National Bank (Jubiläumsfonds). This paper was presented at the scientific session of the American Heart Association, 2002. The study was designed by Dr H J Ankersmit.

\section{Authors' affiliations}

H J Ankersmit*, B Moser, G Roth, M Brunner, E Wolner, Department of Cardiothoracic Surgery, General Hospital of Vienna Medical School, Vienna, Austria

T Weber, J Auer, S Spreitzer, E Lassnig, E Maurer, B Eber, Department of Cardiology, CT and Vascular Surgery, Krankenhaus der Barmherzigen Schwestern, Wels, Austria

P Hartl, Department of Cardiothoracic and Vascular Surgery, Krankenhaus der Barmherzigen Schwestern, Wels, Austria

G Boltz-Nitulescu, Institute of Pathophysiology, General Hospital of Vienna Medical School, Vienna, Austria

E Kvas, Department of Medical Statistics, Krankenhaus der Barmherzigen Schwestern, Wels, Austria

*Also Department of Cardiotharacic and Vascular Surgery, Krankenhaus der Barmherzigen Schwestern

\section{REFERENCES}

1 Ross R. Atherosclerosis: an inflammatory disease. N Engl J Med 1999;340:115-26.

2 Hansson GK. Immune mechanisms in atherosclerosis. Artherioscler Thromb Vasc Biol 2001;21:1876-90.

3 Leinonen M, Saikku P. Evidence for infectious agents in cardiovascular disease and atherosclerosis. Lancet Infect Dis 2002;2:11-7.

4 Gurfinkel E. Link between intracellular pathogens and cardiovascular diseases. Clin Microbiol Infect 1998;4:S33-6.

5 Frostegard J, Ulfgren AK, Nyberg P, et al. Cytokine expression in advanced human atherosclerotic plaques: dominance of pro-inflammatory (Th1) and macrophage-stimulating cytokines. Atherosclerosis 1999; 145:33-45.

6 Koukkunen H, Penttila K, Kemppainen A, et al. C-reactive protein, fibrinogen, interleukin- 6 and tumour necrosis factor-alpha in the prognostic classification of unstable angina pectoris. Ann Med 2001;33:37-47.

7 Gill C, Mestril R, Samali A. Losing heart: the role of apoptosis in heart disease: a novel therapeutic target? FASEB J 2002;16:135-46.

8 Bennett MR. Apoptosis in the cardiovascular system. Heart 2002;87:480-7.

9 Boyle JJ, Bowyer DE, Weissberg PL, et al. Human blood-derived macrophages induce apoptosis in human plaque-derived vascular smooth muscle cells by Fas-ligand/Fas interactions. Arterioscler Thromb Vasc Biol 2001;21:1402-7.

10 Nakajima T, Schulte S, Warrington KJ, et al. T-cell-mediated lysis of endothelial cells in acute coronary syndromes. Circulation 2002;105:570-5.

11 Mallat Z, Benamer H, Hugel B, et al. Elevated levels of shed membrane microparticles with procoagulant potential in the peripheral circulating blood of patients with acute coronary syndromes. Circulation 2000;101:841-3.

12 Braunwald E. Unstable angina: a classification. Circulation 1989;80:410-4.

13 Sullivan DR, Marwick TH, Freedman SB. A new method of scoring coronary angiograms to reflect extent of coronary atherosclerosis and improve correlation with major risk factors. Am Heart J 1990;119:1262-7.

14 Nicholson DW, Ali A, Thornberry NA, et al. Identification and inhibition of the ICE/CED-3 protease necessary for mammalian apoptosis. Nature 1995;376:37-43. 
15 Los M. Stroh C, Janicke RU, et al. Caspases: more than just killers? Trends Immunol 2001;22:31-4.

16 Thornberry NA, Molineaux SM. Interleukin-1 $\beta$ converting enzyme: a novel cysteine protease required for IL-1 $\beta$ production and implicated in programmed cell death. Protein Sci 1995:4:3-12.

17 Gu Y, Kuida K, Tsutsui $\mathrm{H}$, et al. Activation of IFN- $\gamma$ inducing factor mediated by IL-1 $\beta$ converting enzyme. Science 1997;275:206-9

18 Schonbeck U, Herzberg M, Petersen A, et al. Human vascular smooth muscle express interleukin- $1 \beta$ converting enzyme (ICE), but inhibit processing of interleukin-1 $\beta$ precursor by ICE. J Exp Med 1997: 185:1287-94.

19 Kid VJ. Proteolytic activities that mediate apoptosis. Annu Rev Physiol 1998:60:533-73

20 Kühnel F, Zender L, Paul Y et al. NFאB mediates apoptosis through transcriptional activation of Fas (CD95) in adenoviral hepatitis. J Biol Chem 2000;275:6421-7.
21 Vaux DL, Silke J. Mammalian mitochondrial IAP binding proteins. Biochem Biophys Res Commun 2003;304:499-504.

22 Cheng J, Zhou T, Liu C, et al. Protection from Fas-mediated apoptosis by a soluble form of the Fas molecule. Science 1994;263:1759-62.

23 Wang T, Chunming D, Stevenson SC, et al. Overexpression of soluble Fas attenuates transplant arteriosclerosis in rat aortic allografts. Circulation 2002; 106:1536-42.

24 Hebert MJ, Masse M, Vigneault N, et al. Soluble Fas is a marker of coronary artery disease in patients with end-stage renal disease. Am J Kidney Dis 2001;38:1271-6

25 Sata M, Walsh K. TNF- $\alpha$ regulation of Fas ligand expression on the vascular endothelium modulates leukocyte extravasation. Nat Med 1998;4:415-20.

26 Tanaka M, Suda T, Haze K, et al. Fas ligand in human serum. Nat Med 1996:2:317-22.

27 Okura T, Watanabe S, Jiang $Y$, et al. Soluble Fas and atherosclerosis in hypertensive patients. J Hypertens 2002;20:895-8.

\section{IMAGES IN CARDIOLOGY}

\section{New combined treatments avoided transplantation in a child with severe pulmonary hypertension}

$\mathrm{T}$

herapeutic options for the management of pulmonary hypertension have been limited for many years. However, recent progresses in the understanding of its pathology have led to the introduction of new treatments that have changed its prognosis, such as the continuous infusion of prostacyclin. Several other treatments (oral, inhaled, or subcutaneous prostacyclin, phosphodiesterase inhibitors, and endothelin receptor blockers) have shown beneficial effects in recent trials. An 8 year old boy with severe primary pulmonary hypertension showed a dramatic improvement following combined treatment with inhaled iloprost (a prostacylin analogue) and oral bosentan (a dual endothelin receptor blocker). In the six minute walk test he increased the distance from $295 \mathrm{~m}$ before bosentan to $400 \mathrm{~m}$ after three months of combined treatment. Dramatic changes were observed at echocardiography. Echocardiographic short axis views were taken at the same time in the cardiac cycle before combined treatment (panel A) and three months after combined treatment of iloprost and bosentan (panel B). There was a significant reduction in right ventricular (RV) size and changes in interventricular septal curvature (IVS), which went from flat before treatment (panel A) to normal left to right on combined treatment (panel B). Echocardiography showed a decrease in right ventricular surface, from $39 \mathrm{~cm}^{2}$ to $34 \mathrm{~cm}^{2}$. The left ventricle (LV) is squeezed by the dilated right ventricle before (panel A) and is almost normal after three months (panel B). This allowed the lung transplantation to be postponed and improved the patient's quality of life.

This case shows that combined therapies may offer further improvement in the therapeutic options for the treatment of pulmonary hypertension. Appropriate clinical trials should be performed to confirm this beneficial result.
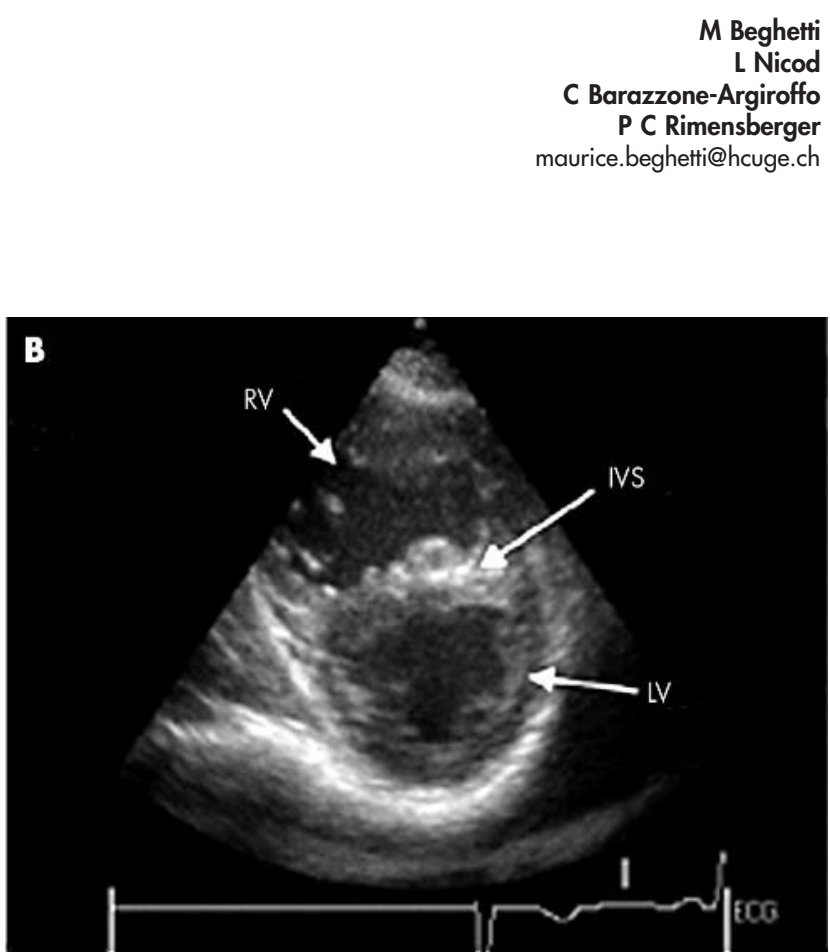